\title{
Flavobacterium scophthalmum sp. nov., a Pathogen of Turbot (Scophthalmus maximus L.)
}

\author{
M. MUDARRIS, ${ }^{1}$ B. AUSTIN,${ }^{2 *}$ P. SEGERS, ${ }^{3}$ M. VANCANNEYT, ${ }^{3}$ B. HOSTE, ${ }^{3}$ AND J. F. BERNARDET ${ }^{4}$ \\ Faculty of Marine Science, King Abdulaziz University, Jeddah, Saudi Arabia 21441 ${ }^{1}$; Department of \\ Biological Sciences, Heriot-Watt University, Riccarton, Edinburgh EH14 4AS, Scotland ${ }^{2}$; Laboratorium voor \\ Microbiologie, Universiteit Gent, B-9000 Ghent, Belgium ${ }^{3}$; and Institut National de la Recherche Agronomique, \\ Unité de Virologie et Immunologie Moléculaires, Centre de Recherches de Jouy-en-Josas,
} Domaine de Vilvert, F-78352 Jouy-en-Josas Cedex, France ${ }^{4}$

\begin{abstract}
Fifty orange-pigmented, gram-negative, rod-shaped isolates were recovered from healthy and diseased turbot and from coastal waters (collected in Scotland). On the basis of the results of an examination of 125 phenotypic characteristics and the results of DNA-DNA and DNA-rRNA hybridization experiments, we concluded that these isolates are members of a new species in the genus Flavobacterium, for which the name Flavobacterium scophthalmum is proposed. The type strain is CCM 4109 (= LMG 13028).
\end{abstract}

Several species of orange- or yellow-pigmented, rod-shaped bacteria that have low DNA guanine-plus-cytosine $(\mathrm{G}+\mathrm{C})$ contents (i.e., Cytophaga, Flavobacterium, and Flexibacter species) have been associated with gill diseases of freshwater and marine fish (3). In 1987, during investigations of the microflora of healthy and diseased turbot (Scophthalmus maximus L.), members of a new group of bacteria that have thick cell walls were isolated (19). These organisms caused gill hyperplasia and systemic hemorrhagic septicemia in turbot. Externally, hemorrhaging was apparent in the eyes, skin, and jaw. Internally, there was necrosis or hemorrhaging in the brain, stomach, intestinal tract, liver, and kidney. These bacterial isolates were studied taxonomically, and we propose that they are members of a new species of the genus Flavobacterium, Flavobacterium scophthalmum.

\section{MATERIALS AND METHODS}

Bacterial isolates. Fifty gram-negative, orange-pigmented bacterial strains were isolated during 1987 from healthy and diseased turbot and from coastal water samples (collected in Scotland) on dilution plates containing medium $\mathrm{K}$, which contains (per liter) $1.0 \mathrm{~g}$ of yeast extract (Oxoid, Basingstoke, England), $5.0 \mathrm{~g}$ of beef extract (Oxoid), $6.0 \mathrm{~g}$ of casein (Oxoid), $2.0 \mathrm{~g}$ of tryptone (Oxoid), $1.0 \mathrm{~g}$ of anhydrous calcium chloride, $15.0 \mathrm{~g}$ of agar (Oxoid no. 1), and $750 \mathrm{ml}$ of seawater (aged for 30 days); the $\mathrm{pH}$ of this medium is 7.2 (18). Pure cultures were maintained on marine 2216E agar (Difco Laboratories, Detroit, Mich.), medium K, and tryptone soya agar (TSA) (Oxoid) at $4^{\circ} \mathrm{C}$, with subculturing every 6 to 8 weeks. The hypothetical median organism, designated strain $\mathrm{MM}^{\mathbf{T}}$ (= CCM $4109^{\mathrm{T}}=$ LMG $\left.13028^{\mathrm{T}}\right)(\mathrm{T}=$ type strain), as calculated by the method of Liston et al. (15), was used for electron microscopic studies. Strain $\mathrm{MM}^{\mathbf{T}}$ and six other representative isolates (strains MM1A [= LMG 13029], MM1B [= LMG 13030], MM1D [= LMG 13031], MM2B [= LMG 13032], MM2C [= LMG 13033], and MM4 [= LMG 13034]) were used to determine the DNA base composition and for DNADNA and DNA-rRNA hybridization experiments, fatty acid analyses, and API ZYM tests (BioMérieux SA, Marcy l'Etoile, France). Forty-eight authentic cultures representing Cyto-

\footnotetext{
${ }^{*}$ Corresponding author. Phone: 44-31-451-3452. Fax: 44-31-4513009 .
}

phaga, Flavobacterium, Flexibacter, Microscilla, and Weeksella species were also used for DNA-DNA hybridization experiments, and some of these strains were used for DNA-rRNA hybridization experiments and API ZYM tests. The reference cultures used were type strains or authentic strains obtained from major collections and were grown at 18 to $25^{\circ} \mathrm{C}$ on Anacker-Ordal medium (2), Dubos medium (21), nutrient agar (Oxoid), TSA, the medium for marine flexibacteria (14), or marine $2216 \mathrm{E}$ agar, as appropriate (4).

Characterization of the isolates. All of the isolates obtained from turbot and coastal waters were examined for 125 phenotypic characteristics, as described previously (19). The tests used were those considered to have differential value for identification of gram-negative yellow- or orange-pigmented bacteria (12). The methods used were adapted from the methods of Christensen (6), Cowan (7), van der Meulen et al. (27), and Gerhardt et al. (11). The characteristics studied included colonial morphology (including the presence of flexirubin-like pigments, as determined by the development of a red color after the addition of $20 \%$ [wt/vol] potassium hydroxide [19]); cell morphology; the presence of gliding motility on Anacker-Ordal medium (2); oxidative or fermentative metabolism of glucose; production of ammonia from arginine, arginine dihydrolase, catalase, $\mathrm{H}_{2} \mathrm{~S}$, indole, lysine and ornithine decarboxylases, oxidase, phenylalanine deaminase, and phosphatase; the methyl red test; nitrate reduction; the VogesProskauer reaction; production of acid from arabinose, cellobiose, glucose, lactose, mannitol, raffinose, salicin, sucrose, and xylose; degradation of esculin, agar, blood (beta-hemolysis), casein, cellulose, chitin, DNA, gelatin, starch, tributyrin, Tween 20 , Tween 40 , Tween 60 , Tween 80 , Tween 85 , tyrosine, and urea; utilization of alginate, L-arabinose, L-arabitol, carboxymethyl cellulose, cellobiose, erythritol, ethanol, D-fructose, D-glucose, glycerol, heparin, inositol, inulin, L-leucine, lysine, maltose, mannitol, methanol, L-methionine, pectin, Lphenylalanine, polypectate, raffinose, D-ribose, sodium benzoate, sodium citrate, sodium succinate, sorbitol, sucrose, $m$ xylitol, and D-xylose as sole sources of carbon for energy and growth; utilization of sodium nitrate, vitamin-free Casamino Acids and yeast extract as sources of nitrogen; growth in the presence of 0 to $5 \%$ (wt/vol) $\mathrm{NaCl}$; growth at 4 to $42^{\circ} \mathrm{C}$; growth on MacConkey agar (Oxoid); and susceptibility to ampicillin (10 and $25 \mu \mathrm{g})$, carbenicillin $(100 \mu \mathrm{g})$, chloramphenicol (10 and $50 \mu \mathrm{g})$, chlortetracycline $(10 \mu \mathrm{g})$, cephaloridone $(25 \mu \mathrm{g})$, cloxacillin $(5 \mu \mathrm{g})$, colistin sulfate $(10 \mu \mathrm{g})$, cotrimoxazole $(25$ 
$\mu \mathrm{g})$, erythromycin $(10 \mu \mathrm{g})$, furazolidone $(50 \mu \mathrm{g})$, fusidic acid $(10 \mu \mathrm{g})$, gentamicin $(10 \mu \mathrm{g})$, kanamycin $(30 \mu \mathrm{g})$, lincomycin $(2$ $\mu \mathrm{g})$, methicillin $(10 \mu \mathrm{g})$, nalidixic acid (5 and $30 \mu \mathrm{g})$, neomycin $(10 \mu \mathrm{g})$, nitrofurantoin $(200 \mu \mathrm{g})$, novobiocin $(5 \mu \mathrm{g})$, oleandomycin $(5 \mu \mathrm{g})$, oxytetracycline $(10 \mu \mathrm{g})$, penicillin $\mathrm{G}$ (1.5 IU), streptomycin (10 and $25 \mu \mathrm{g}$ ), sulfadiazine $(50 \mu \mathrm{g})$, sulfafurazole $(100$ and $500 \mu \mathrm{g})$, and tetracycline $(10$ and $50 \mu \mathrm{g})$. When possible, medium $\mathrm{K}$ was used as the basal medium, and test results were usually recorded after incubation at $25^{\circ} \mathrm{C}$ for 14 days. In addition, seven representative isolates were used to determine the hydrolysis of 19 substrates in the API ZYM system following incubation at $22^{\circ} \mathrm{C}$ for $12 \mathrm{~h}$. Hydrolysis resulted in the production of color, the intensity of which was measured on a scale of 0 to 5 (4).

DNA base composition. The methods used to extract and purify DNAs have been described previously (5). The base compositions were determined by thermal denaturation and were calculated by using the equation of Marmur and Doty (16), as modified by De Ley (8).

DNA-DNA hybridization. The degree of DNA-DNA binding, expressed as a percentage, was determined spectrophotometrically by using the initial renaturation rate method (9). The renaturation rates were measured in $2 \times$ SSC $(1 \times$ SSC is $0.15 \mathrm{M} \mathrm{NaCl}$ plus $0.015 \mathrm{M}$ trisodium citrate, $\mathrm{pH} \mathrm{7.0)}$ at the optimal renaturation temperature $\left(64.9^{\circ} \mathrm{C}\right)$. Each experiment was repeated at least once.

DNA-rRNA hybridization. rRNAs from Flavobacterium indologenes LMG $8337^{\mathbf{T}}$, Flavobacterium meningosepticum LMG $12279^{\mathrm{T}}$, and Weeksella zoohelcum LMG $8351^{\mathrm{T}}$ were radioactively labelled in vivo by adding $\left[{ }^{3} \mathrm{H}\right]$ adenine to early-log-phase broth cultures. Labelled $23 \mathrm{~S}$ rRNAs were then prepared by using a procedure slightly modified from the procedure of Aiba et al. (1), as described by Vandamme et al. (26). Fixation of single-stranded DNA on cellulose nitrate filters, DNA-rRNA hybridization, RNase treatment, and determination of the thermostability of the hybrids were performed as previously described (10).

Gas chromatographic analysis of cellular FAMEs. Cultures of strains CCM 4109 ${ }^{\mathrm{T}}$, LMG 13029, LMG 13030, LMG 13031, LMG 13032, LMG 13033, and LMG 13034 were grown for 24 $h$ at $28^{\circ} \mathrm{C}$ on TSA and were harvested, and the cells were used for extracting fatty acid methyl esters (FAMEs). The FAMEs were then separated by gas-liquid chromatography (28). FAME fingerprints were identified by using the Microbial Identification System software package (MIS version no. 3.7, obtained from Microbial ID, Inc., Newark, Del.) and a calibration mixture of known standards (Hewlett-Packard). FAME profiles were compared by performing a numerical analysis (28).

Transmission electron microscopy. Dense suspensions containing approximately $10^{9}$ cells per $\mathrm{ml}$ in $0.85 \%$ (wt/vol) saline were prepared from 48 -h plate cultures. The suspensions were fixed overnight in $0.5 \%$ ( $\mathrm{vol} / \mathrm{vol})$ buffered $(\mathrm{pH} \mathrm{7.4)}$ glutaraldehyde (EMscope Laboratories, Watford, England). The preparations were stained with $1 \%$ (vol/vol) phosphotungstic acid (EMscope) and then examined to determine cell morphology. Thin sections were also prepared and stained by using the methods of Watson (29), Millonig (17), and Reynolds (22). All specimens were examined with an AEI model EM6G transmission electron microscope.

Identification of the orange chromogens. We attempted to identify the isolates by using the diagnostic schemes described by Holmes et al. (12) and by using the descriptions of all relevant taxa published in the Approved Lists of Bacterial Names (24) and the supplements to the Approved Lists.

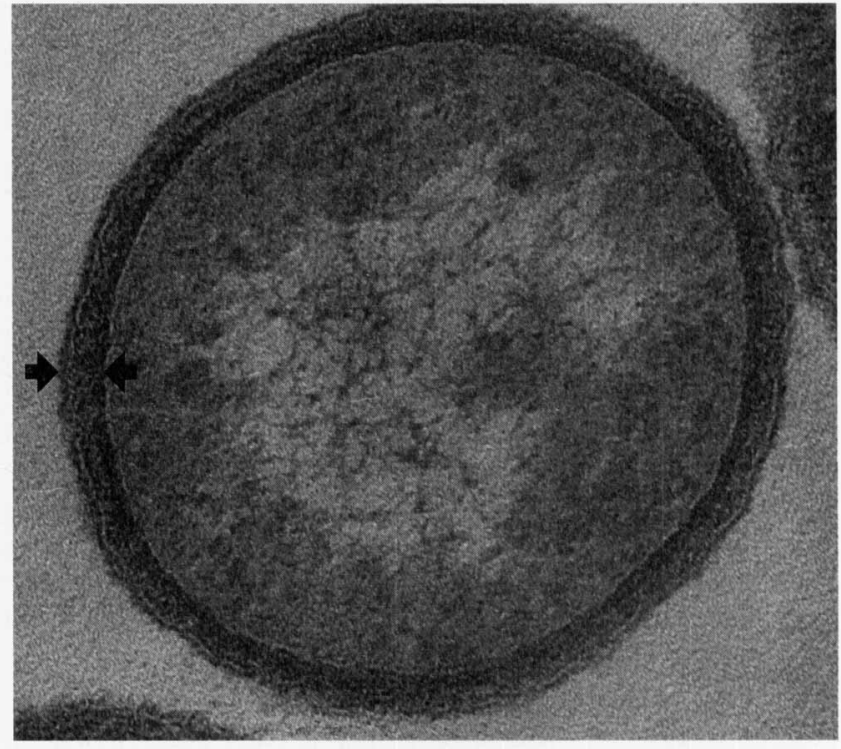

FIG. 1. Transmission electron micrograph of a cross section of a strain $M M 1^{\mathrm{T}}$ cell. The arrows indicate the thick wall.

\section{RESULTS AND DISCUSSION}

Phenotypic characterization of the isolates. All of the isolates were members of a homogeneous group and exhibited marked uniformity in their characteristics (19). Round, raised, entire, shiny, smooth, orange-pigmented (nondiffusing, flexirubin-like pigment) colonies that were 5 to $6 \mathrm{~mm}$ in diameter were formed within $48 \mathrm{~h}$ of inoculation at $25^{\circ} \mathrm{C}$ on medium $\mathrm{K}$, marine $2216 \mathrm{E}$ agar, and TSA. Fresh isolates, examined in 1987 , appeared to exhibit gliding motility on Anacker-Ordal medium. However, gliding motility could not be confirmed during a subsequent examination in 1993. Consequently, we considered the cultures nonmotile. The cultures contained uniformly shaped rods that were approximately 2.0 by $0.5 \mu \mathrm{m}$ and had thick (50-nm) cell walls (Fig. 1) after incubation for $18 \mathrm{~h}$. Shorter rods (approximately 1.0 by $0.5 \mu \mathrm{m}$ ) (Fig. 2) were apparent in late-exponential-phase cultures after incubation for $48 \mathrm{~h}$. Resting stages were not observed. The results of the API ZYM tests are shown in Table 1; the results of other tests are described below.

DNA base composition. The $\mathrm{G}+\mathrm{C}$ ratios of the DNAs were calculated to be $34.1,34.2,33.5,34.7,34.5,34.7$, and $33.8 \mathrm{~mol} \%$ for strains CCM 4109 ${ }^{\mathrm{T}}$, LMG 13029, LMG 13030, LMG 13031,

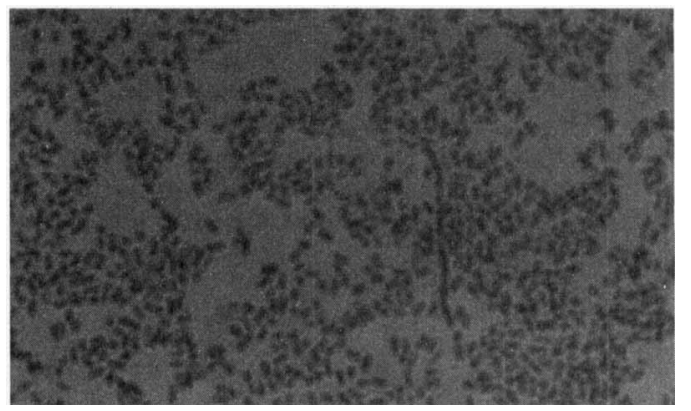

FIG. 2. Photomicrograph of Gram-stained $M M 1^{T}$ cells from a $48-h$ culture on medium $\mathrm{K}$, showing the presence of short rods and some filaments. 
TABLE 1. Profiles for Flavobacterium strains obtained by using the API ZYM system

\begin{tabular}{|c|c|c|c|c|c|c|c|c|c|c|c|c|c|c|c|c|c|c|c|}
\hline \multirow{2}{*}{ Taxon } & \multicolumn{19}{|c|}{ Hydrolysis of the following substrates ${ }^{a}$ : } \\
\hline & A & B & $\mathrm{C}$ & $\mathrm{D}$ & $\mathrm{E}$ & $\mathrm{F}$ & $\mathrm{G}$ & $\mathrm{H}$ & I & $\mathbf{J}$ & $\mathrm{K}$ & $\mathrm{L}$ & M & $\mathrm{N}$ & $\mathrm{O}$ & $P$ & Q & $\mathrm{R}$ & $\mathrm{s}$ \\
\hline Flavobacterium scophthalmum ${ }^{b}$ & 5 & 3 & 4 & 1 & 5 & 4 & 2 & 4 & 1 & 5 & 5 & 0 & 0 & 0 & 3 & 1 & 2 & 0 & 0 \\
\hline Flavobacterium balustinum LMG $8329^{\mathrm{T}}$ & 5 & 1 & 3 & 1 & 5 & 5 & 2 & 2 & 1 & 5 & 5 & 0 & 0 & 0 & 3 & 4 & 2 & 0 & 0 \\
\hline Flavobacterium gleum LMG $8334^{\mathbf{T}}$ & 5 & 2 & 3 & 1 & 5 & 5 & 2 & 2 & 2 & 5 & 5 & 0 & 0 & 0 & 4 & 5 & 4 & 0 & 0 \\
\hline Flavobacterium indologenes LMG $8337^{\mathrm{T}}$ & 5 & 2 & 3 & 1 & 5 & 4 & 2 & 2 & 2 & 5 & 5 & 0 & 0 & 0 & 5 & 0 & 4 & 0 & 0 \\
\hline Flavobacterium indoltheticum LMG & 5 & 2 & 3 & 1 & 5 & 4 & 1 & 0 & 0 & 4 & 4 & 0 & 0 & 0 & 4 & 0 & 3 & 0 & 0 \\
\hline
\end{tabular}

Flavobacterium indoltheticum $\mathrm{LMG}$ $4025^{\mathrm{T}}$

${ }^{a}$ A, 2-naphthyl-phosphate; B, 2-naphthyl-butyrate; C, 2-naphthyl-caprylate; D, 2-naphthyl-myristate; E, L-leucyl-2-naphthylamide; F, L-valyl-2-naphthylamide; G, L-cystyl-2-naphthylamide; H, N-benzoyl-DL-arginine-2-naphthylamide; I, N-glutaryl-phenylalanine-2-naphthylamide; J, 2-naphthyl-phosphate; K, naphthol-AS-BIphosphate; L, 6-Br-2-naphthyl- $\alpha$-D-galactopyranoside; $\mathrm{M}, 2$-naphthyl- $\beta$-D-galactopyranoside; N, naphthol-AS-BI- $\beta$-D-glucuronide; O, 2 -naphthyl- $\alpha$-D-glucopyranoside; $\mathrm{P}, 6$-Br-2-naphthyl- $\beta$-D-glucopyranoside; $\mathrm{Q}, 1$-naphthyl- $N$-acetyl- $\beta$-D-glucosaminide; $\mathrm{R}, 6$-Br-2-naphthyl- $\alpha$-D-mannopyranoside; $\mathrm{S}, 2$-naphthyl- $\alpha$-L-fucopyranoside. The values are API ZYM reaction scores.

${ }^{b}$ Data for strain LMG $13028^{\mathrm{T}}$ and six other strains.

LMG 13032, LMG 13033, and LMG 13034, respectively. The mean for the seven strains was $34.2 \mathrm{~mol} \%$.

DNA-DNA hybridization. The DNA of one of the isolates obtained from turbot (LMG $13028^{\mathrm{T}}$ ) was closely related to the DNAs of six other fresh isolates (levels of homology, 91 to $103 \%$ ). The DNAs of Flavobacterium scophthalmum strains were moderately closely related to the DNAs of Flavobacterium balustinum LMG $8329^{\mathrm{T}}$ (38 to $44 \%$ ) and Flavobacterium indoltheticum LMG $4025^{\mathrm{T}}$ (33 to $38 \%$ ), but not to the DNAs of Flavobacterium gleum LMG $8334^{\mathrm{T}}(10 \%)$ and Flavobacterium indologenes LMG $8337^{\mathrm{T}}$ (13\%) (Table 2).

Preliminary DNA-DNA hybridization experiments were performed at $60^{\circ} \mathrm{C}$ by using the S1-DE81 method (20) and labelled DNAs of Flavobacterium scophthalmum LMG $13028^{\mathrm{T}}$, other Flavobacterium scophthalmum strains (Table 2), and reference strains (3a). Comparable binding values were found between the Flavobacterium scophthalmum strains (85 to $104 \%)$. No significant binding values were obtained when labelled DNA from Flavobacterium scophthalmum LMG $13028^{\mathrm{T}}$ was hybridized with DNAs from Cytophaga agarovorans NCIMB $2217^{\mathrm{T}}$ (National Collection of Industrial and Marine
Bacteria, Aberdeen, Scotland), "Cytophaga allerginae" ATCC 35408 (American Type Culture Collection, Rockville, Md.), Cytophaga aprica ATCC $23126^{\mathrm{T}}$, Cytophaga aquatilis DSM $2063^{\mathrm{T}}$ (Deutsche Sammlung von Mikroorganismen, Braunschweig, Germany), "Cytophaga arvensicola" JCM 2836 (Japan Collection of Microorganisms, Saitama, Japan), Cytophaga aurantiaca NCIMB $8628^{\mathrm{T}}$, Cytophaga diffluens NCIMB $1402^{\mathrm{T}}$, Cytophaga fermentans NCIMB $2218^{\mathrm{T}}$, Cytophaga flevensis DSM $1076^{\mathrm{T}}$, "Cytophaga heparina" NCIMB 9290', Cytophaga hutchinsonii NCIMB $9469^{\mathrm{T}}$, Cytophaga johnsonae DSM $2064^{\mathrm{T}}$, Cytophaga latercula NCIMB $1399^{\mathrm{T}}$, Cytophaga lytica NCIMB $1423^{\mathrm{T}}$, Cytophaga marinoflava NCIMB $397^{\mathrm{T}}$, Cytophaga pectinovora NCIMB $9059^{\mathrm{T}}$, Cytophaga saccharophila NCIMB $2072^{\mathrm{T}}$, Cytophaga salmonicolor NCIMB 2216 ${ }^{\mathrm{T}}$, Cytophaga succinicans NCIMB $2277^{\mathrm{T}}$, Cytophaga uliginosa NCIMB $1863^{\mathrm{T}}$, Flavobacterium aquatile NCIMB $8694^{\mathrm{T}}$, Flexibacter aurantiacus NCIMB $1382^{\mathrm{T}}$, Flexibacter canadensis ATCC $29591^{\mathrm{T}}$, Flexibacter columnaris NCIMB $2248^{\mathrm{T}}$, Flexibacter elegans NCIMB $1385^{\mathrm{T}}$, Flexibacter filiformis ATCC $29495^{\mathrm{T}}$, Flexibacter flexilis NCIMB $12853^{\mathrm{T}}$, Flexibacter litoralis NCIMB $1366^{\mathrm{T}}$, Flexibacter maritimus NCIMB $2154^{\mathrm{T}}$, Flexibacter ovolyticus NCIMB

TABLE 2. Levels of DNA-DNA relatedness for Flavobacterium scophthalmum strains and strains of other Flavobacterium species belonging to the same rRNA branch

\begin{tabular}{|c|c|c|c|c|c|c|c|c|c|c|c|}
\hline \multirow[b]{2}{*}{ Strain } & \multicolumn{11}{|c|}{$\%$ of DNA-DNA binding with ${ }^{a}:$} \\
\hline & 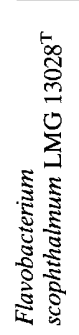 & 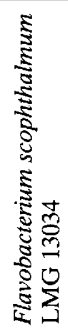 & 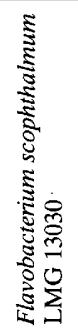 & 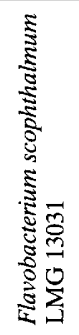 & 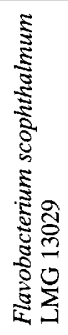 & 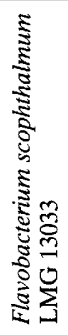 & 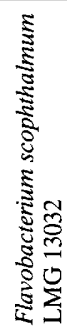 & 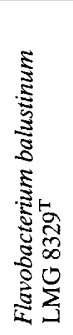 & 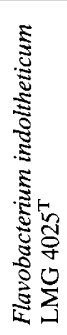 & 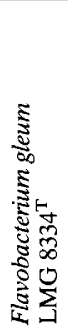 & 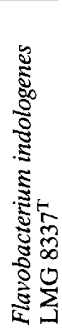 \\
\hline Flavobacterium scophthalmum LMG $13028^{\mathrm{T}}$ & 100 & & & & & & & & & & \\
\hline Flavobacterium scophthalmum LMG 13034 & 103 & 100 & & & & & & & & & \\
\hline Flavobacterium scophthalmum LMG 13030 & 102 & & 100 & & & & & & & & \\
\hline Flavobacterium scophthalmum LMG 13031 & 101 & & & 100 & & & & & & & \\
\hline Flavobacterium scophthalmum LMG 13029 & 99 & & & & 100 & & & & & & \\
\hline Flavobacterium scophthalmum LMG 13033 & 95 & & & & & 100 & & & & & \\
\hline Flavobacterium scophthalmum LMG 13032 & 91 & & & & & & 100 & & & & \\
\hline Flavobacterium balustinum LMG $8329^{\mathrm{T}}$ & 44 & 44 & & & & 41 & 38 & 100 & & & \\
\hline Flavobacterium indoltheticum $\mathrm{LMG} 4025^{\mathrm{T}}$ & 37 & 38 & & & & 33 & 32 & 35 & 100 & & \\
\hline Flavobacterium gleum LMG $8334^{\mathrm{T}}$ & 10 & & & & & & & & 14 & 100 & \\
\hline Flavobacterium indologenes LMG $8337^{\mathrm{T}}$ & 13 & & & & & & & & & 25 & 100 \\
\hline
\end{tabular}

\footnotetext{
${ }^{a}$ Each value is the average of the values from at least two experiments.
} 
TABLE 3. $T_{m(e)}$ values for DNA-rRNA hybrids

\begin{tabular}{|c|c|c|c|}
\hline \multirow[b]{2}{*}{ DNA from: } & \multicolumn{3}{|c|}{$T_{m(e)}\left({ }^{\circ} \mathrm{C}\right)$ with rRNA from ${ }^{a}:$} \\
\hline & $\begin{array}{c}\text { Flavobacterium indologenes } \\
\text { LMG } 8337^{\mathrm{T}}\end{array}$ & $\begin{array}{c}\text { Flavobacterium meningosepticum } \\
\text { LMG } 12279^{\mathrm{T}}\end{array}$ & $\begin{array}{l}\text { W. zoohelcum } \\
\text { LMG } 8351^{\mathrm{T}}\end{array}$ \\
\hline Flavobacterium scophthalmum LMG $13028^{\mathrm{T}}$ & 75.0 & 71.3 & 71.8 \\
\hline Flavobacterium scophthalmum LMG 13032 & 75.9 & & \\
\hline Flavobacterium balustinum LMG $8329^{\mathrm{T}}$ & 73.7 & & 70.6 \\
\hline Flavobacterium gleum LMG $8334^{\mathrm{T}}$ & 76.2 & 73.3 & 73.8 \\
\hline Flavobacterium indologenes $\mathrm{LMG} 8337^{\mathrm{T}}$ & 78.1 & 70.6 & 72.5 \\
\hline Flavobacterium indoltheticum LMG $4025^{\mathrm{T}}$ & 75.3 & & 73.1 \\
\hline Flavobacterium meningosepticum LMG $12279^{\mathrm{T}}$ & 72.2 & 75.4 & 71.9 \\
\hline W. zoohelcum LMG $8351^{\mathrm{T}}$ & 71.7 & 71.8 & 75.0 \\
\hline
\end{tabular}

${ }^{a}$ Some of the data are from reference 23 .

$13127^{\mathrm{T}}$, Flexibacter polymorphus ATCC $27820^{\mathrm{T}}$, Flexibacter psychrophilus NCIMB $1947^{\mathrm{T}}$, Flexibacter roseolus NCIMB $1433^{\mathrm{T}}$, Flexibacter ruber NCIMB $1436^{\mathrm{T}}$, Flexibacter sancti NCIMB $1379^{\mathrm{T}}$, "Microscilla aggregans" NCIMB $1443^{\mathrm{T}}$, "Microscilla arenaria" NCIMB $1413^{\mathrm{T}}$, "Microscilla furvescens" NCIMB $1419^{\mathrm{T}}$, Microscilla marina NCIMB $1400^{\mathrm{T}}$, "Microscilla sericea" NCIMB $1403^{\mathrm{T}}$, and "Microscilla tractuosa" NCIMB $1408^{\mathrm{T}}$.

DNA-rRNA hybridization. The results of the DNA-rRNA hybridization experiments are shown in Table 3 and are presented as a dendrogram based on the melting temperature of elution $\left[T_{m(e)}\right]$ values of the hybrids in Fig. 3; each DNArRNA hybrid was characterized by its $T_{m(e)}$ value, the temperature at which $50 \%$ of the hybrid was denatured. The $T_{m(e)}$ values for the reciprocal hybridizations between all of the strains on each branch were used to calculate the average linkage level for each pair of strains. After the results of a screening study revealed that the environmental isolates gave low levels of hybridization with the rRNA probes for the branches containing most Cytophaga and Flexibacter species (4a), the DNAs of these organisms were tested with the rRNA probes for Flavobacterium indologenes, Flavobacterium meningosepticum, and W. zoohelcum. Previous studies had revealed that these three bacterial species belong to the same rRNA homology branch within rRNA superfamily V, together with Flavobacterium gleum, Flavobacterium balustinum, Flavobacterium indoltheticum, and Riemerella anatipestifer (23). The data from the DNA-rRNA hybridization experiments performed with the DNAs from two environmental isolates and three rRNA probes revealed that the environmental isolates are most closely related to Flavobacterium indologenes and are related at lower levels to Flavobacterium meningosepticum and $W$. zoohelcum. The $T_{m(e)}$ values of the environmental isolates with Flavobacterium indologenes placed these organisms in the tight genomic cluster containing Flavobacterium balustinum, Flavobacterium gleum, and Flavobacterium indoltheticum.

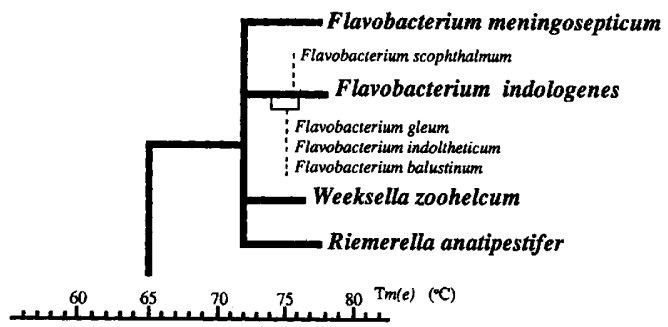

FIG. 3. Position of Flavobacterium scophthalmum on a partial dendrogram of rRNA superfamily $\mathrm{V}$.
Gas chromatographic analysis of cellular FAMEs. The fatty acid profiles of seven environmental isolates were determined and compared with the profiles of their closest phylogenetic neighbors. The average fatty acid compositions of the isolates and of the reference strains are shown in Table 4. At least 15 fatty acids occurred in all of the environmental isolates. Branched fatty acids were dominant in the fatty acids of all of the strains studied. The four major fatty acids (fatty acids with mean levels greater than $5 \%$ ) were 15:0 iso, iso 17:1 $\omega 9 \mathrm{c}, 17: 0$ iso-3-OH, and summed feature 4 (i.e., 15:0 iso-2-OH and/or 16:1 $\omega 7 \mathrm{t}$, which could not be separated from each other by gas chromatography). There were few differences between the fatty acid compositions of the environmental isolates and the fatty acid compositions of the other species studied.

Evidence for assignment to the genus Flavobacterium and proposal for a new species. The environmental isolates had the overall characteristics of the genus Flavobacterium (12); viz., the cells were aerobic, short, (orange-) pigmented (the pigment was shown to be flexirubin by the development of a red color after the addition of $20 \%$ [wt/vol] potassium hydroxide), gram-negative, apparently nonmotile rods without resting stages, which had low DNA G+C contents (30 to $42 \mathrm{~mol} \%$ ) and produced catalase, oxidase and phosphatase. The chemotaxonomy data, which revealed the presence of branched-chain fatty acids and branched-chain hydroxy fatty acids, are also consistent with identification of these bacteria as flavobacteria or related organisms $(12,25)$. On the basis of the results of DNA hybridization experiments and phenotypic characterization tests, the environmental isolates could not be placed in any of the species included on the Approved Lists of Bacterial Names (24) and the supplements to the Approved Lists or in taxa now regarded as incertae sedis. Consequently, we propose that these isolates should be placed in a new species, Flavobacterium scophthalmum (scoph. thal' mum. N.L. n. Scophthalmus, turbot; N.L. adj. scophthalmum, pertaining to turbot).

Description of Flavobacterium scophthalmum sp. nov. Uniformly shaped gram-negative rods that are approximately 2.0 by $0.5 \mu \mathrm{m}$ and have rounded ends after incubation for $18 \mathrm{~h}$. Shorter rods, approximately 1.0 by $0.5 \mu \mathrm{m}$, are present in late-exponential-phase cultures after incubation for $48 \mathrm{~h}$.

Fresh isolates appear to exhibit gliding motility; flagella are not produced. However, after storage, the presence of gliding motility cannot be confirmed. Therefore, isolates may be considered nonmotile.

The cell wall is approximately $50 \mathrm{~nm}$ thick (Fig. 1).

Resting stages are not observed.

Colonies on medium K (18), marine 2216E agar, and TSA are shiny, smooth, round, raised, entire, and 5 to $6 \mathrm{~mm}$ in diameter after incubation for $48 \mathrm{~h}$ at $25^{\circ} \mathrm{C}$. 
TABLE 4. Fatty acid compositions of Flavobacterium scophthalmum and allied bacteria ${ }^{a}$

\begin{tabular}{|c|c|c|c|c|c|c|c|}
\hline \multirow[b]{2}{*}{ Fatty acid } & \multicolumn{7}{|c|}{$\%$ in: } \\
\hline & $\begin{array}{l}\text { Flavobacterium } \\
\text { scophthalmum } \\
\text { (7 strains) }\end{array}$ & $\begin{array}{l}\text { Flavobacterium } \\
\text { balustinum } \\
\text { LMG } 8329^{\mathrm{T}}\end{array}$ & $\begin{array}{l}\text { Flavobacterium } \\
\text { indoltheticum } \\
\text { LMG } 4025^{\mathrm{T}}\end{array}$ & $\begin{array}{l}\text { Flavobacterium } \\
\text { indologenes } \\
\text { LMG } 8337^{\mathrm{T}}\end{array}$ & $\begin{array}{l}\text { Flavobacterium } \\
\text { gleum LMG } \\
8334^{\mathrm{T}}\end{array}$ & $\begin{array}{l}\text { Flavobacterium } \\
\text { meningosepticum } \\
\text { LMG } 12279^{\mathrm{T}}\end{array}$ & $\begin{array}{l}\text { W. zoohelcum } \\
\text { LMG } 8351^{\mathrm{T}}\end{array}$ \\
\hline $13: 0$ iso & $\operatorname{Tr}$ & $\operatorname{Tr}$ & ND & $\operatorname{Tr}$ & $\operatorname{Tr}$ & 1.4 & 1.7 \\
\hline $\begin{array}{l}\text { Unknown ECL } \\
13.566^{b}\end{array}$ & $3.3 \pm 0.5$ & 1.6 & $\operatorname{Tr}$ & 1.2 & 1.6 & 1.5 & 1.0 \\
\hline $15: 0$ iso & $34.9 \pm 0.5$ & 32.3 & 29.5 & 30.8 & 31.4 & 41.2 & 49.1 \\
\hline $15: 0$ iso-3-OH & $2.9 \pm 0.1$ & 2.7 & 2.2 & 2.7 & 2.5 & 3.5 & 4.0 \\
\hline 15:0 anteiso & $\mathrm{Tr}$ & $\operatorname{Tr}$ & 4.9 & $\operatorname{Tr}$ & $\operatorname{Tr}$ & 2.2 & ND \\
\hline 16:0 & $1.1 \pm 0.1$ & 1.6 & $\operatorname{Tr}$ & $\operatorname{Tr}$ & $\operatorname{Tr}$ & $\mathrm{Tr}$ & $\mathrm{Tr}$ \\
\hline $16: 03-\mathrm{OH}$ & $1.3 \pm 0.1$ & 1.4 & $\operatorname{Tr}$ & $\operatorname{Tr}$ & 1.1 & 2.2 & ND \\
\hline $16: 0$ iso-3-OH & $\operatorname{Tr}$ & $\operatorname{Tr}$ & 1.2 & ND & $\operatorname{Tr}$ & $\operatorname{Tr}$ & ND \\
\hline $\begin{array}{l}\text { Unknown ECL } \\
16.580^{b}\end{array}$ & $1.7 \pm 0.2$ & 1.3 & 1.3 & 1.7 & 1.9 & 1.7 & $\operatorname{Tr}$ \\
\hline 17:0 2-OH & $\operatorname{Tr}$ & $\operatorname{Tr}$ & 2.7 & ND & ND & $\operatorname{Tr}$ & ND \\
\hline $17: 0$ iso & $1.1 \pm 0.1$ & 1.0 & $\operatorname{Tr}$ & $\operatorname{Tr}$ & $\operatorname{Tr}$ & $\operatorname{Tr}$ & ND \\
\hline $17: 0$ iso-3-OH & $17.1 \pm 0.2$ & 16.8 & 15.4 & 18.1 & 19.0 & 16.3 & 11.5 \\
\hline iso $17: 1 \omega 9 \mathrm{c}$ & $21.3 \pm 0.4$ & 27.1 & 24.6 & 27.7 & 24.9 & 7.0 & 18.4 \\
\hline $18: 1 \omega 5 c$ & $\operatorname{Tr}$ & $\mathrm{Tr}$ & $\mathrm{Tr}$ & $\operatorname{Tr}$ & $\operatorname{Tr}$ & $\operatorname{Tr}$ & 1.5 \\
\hline Summed feature $4^{c}$ & $11.8 \pm 0.6$ & 9.2 & 12.0 & 12.9 & 12.8 & 18.0 & 9.6 \\
\hline Summed feature $5^{d}$ & ND & $\operatorname{Tr}$ & ND & $\operatorname{Tr}$ & $\operatorname{Tr}$ & $\operatorname{Tr}$ & 1.6 \\
\hline
\end{tabular}

\footnotetext{
${ }^{a}$ Fatty acids which accounted for $<1 \%$ of the total fatty acids in all of the strains studied were not included. For Flavobacterium scophthalmum, the means and standard deviations are given. $\mathrm{Tr}$, trace $(<1 \%)$; ND, not detected.

${ }^{b}$ The identities of the fatty acids which have equivalent chain lengths (ECL) of 13.566 and 16.580 are not known.

$c$ 15:0 iso-2-OH and 16:1 $\omega 7 \mathrm{t}$ could not be separated from each other by gas chromatography by using the MIS system and together were considered summed feature 4 .

d 17:1 iso 1 and 17:1 anteiso B could not be separated from each other by gas chromatography by using the MIS system and together were considered summed feature 5 .
}

A nondiffusible, nonfluorescent orange (flexirubin-like) pigment is produced.

Broth cultures are uniformly turbid.

Cultures are chemoorganotrophic (metabolism is respiratory and fermentative).

Nitrates are not reduced.

Ammonia is produced from arginine; catalase, oxidase, phenylalanine deaminase, and phosphatase are produced, but arginine dihydrolase, $\mathrm{H}_{2} \mathrm{~S}$, indole, and lysine and ornithine decarboxylases are not produced.

The methyl red test and the Voges-Proskauer reaction are negative.

Esculin, blood (beta-hemolysis), casein, DNA, gelatin, tributyrin, Tween 20, Tween 40, Tween 60 , Tween 80 , Tween 85 , tyrosine, and urea are degraded, but agar, cellulose, chitin, and starch are not degraded.

Acid is not readily produced from carbohydrates (arabinose, cellobiose, glucose, lactose, mannitol, raffinose, salicin, sucrose, and xylose).

Cellobiose, ethanol, D-fructose, D-glucose, maltose, pectin, polypectate, and $m$-xylitol are utilized as sole sources of carbon for energy and growth, but alginate, L-arabinose, L-arabitol, carboxymethyl cellulose, erythritol, glycerol, heparin, inositol, inulin, L-leucine, lysine, mannitol, methanol, L-methionine, L-phenylalanine, $D$-ribose, raffinose, sodium benzoate, sodium citrate, sodium succinate, sorbitol, sucrose, and D-xylose are not utilized.

Hydrolyzes the following substrates (as determined with the API ZYM system; scores of 2 to 5 are considered positive): 2-naphthyl-phosphate, 2-naphthyl-butyrate, 2-naphthyl-caprylate, L-leucyl-2-naphthylamide, L-valyl-2-naphthylamide, L-cystyl-2-naphthylamide, $N$-benzoyl-DL-arginine-2-naphthylamide, 2-naphthyl-phosphate, naphthol-AS-BI-phosphate, 2-naphthyl$\alpha$-D-glucopyranoside, and 1-naphthyl- $N$-acetyl- $\beta$-D-glucosaminide.
Does not hydrolyze the following substrates (as determined with the API ZYM system; scores 0 and 1 are considered negative): 2-naphthyl-myristate, $N$-glutaryl-phenylalanine-2naphthylamide, 6 - $\mathrm{Br}-2$-naphthyl- $\alpha$-D-galactopyranoside, 2-naphthyl- $\beta$-D-galactopyranoside, naphthol-AS-BI- $\beta$-D-glucuronide, 6-Br-2-naphthyl- $\beta$-D-glucopyranoside, $6-\mathrm{Br}-2-$-naphthyl- $\alpha-\mathrm{D}-$ mannopyranoside, and 2-naphthyl- $\alpha$-L-fucopyranoside.

Sodium nitrate, vitamin-free Casamino Acids, and yeast extract are utilized as nitrogen sources.

Growth occurs at 15 to $25^{\circ} \mathrm{C}$ (weak growth occurs at $4^{\circ} \mathrm{C}$ and no growth occurs at $35^{\circ} \mathrm{C}$ ) and in the presence of 0 to $4 \% \mathrm{NaCl}$, but not in the presence of $5 \%$ (wt/vol) $\mathrm{NaCl}$, or on MacConkey agar.

All of the strains which we studied are characterized by the following fatty acids: $15: 0$ iso, 15:0 iso-3-OH, 16:0, 16:0 3-OH, $17: 0$ iso, $17: 0$ iso-3-OH, iso $17: 1 \omega 9 \mathrm{c}$, summed feature 4 (i.e., $15: 0$ iso-2-OH and/or $16: 1 \omega 7 \mathrm{t}$ ), and two unidentified fatty acids with equivalent chain lengths of 13.556 and 16.580 .

Cultures are found in coastal waters and are capable of producing gill disease and hemorrhagic septicemia in turbot.

The $\mathrm{G}+\mathrm{C}$ content of the DNA is 33 to $35 \mathrm{~mol} \%$.

The type strain is MM1, which was isolated in 1987 from the gills of diseased turbot in Scotland; a culture of this strain has been deposited in the Czechoslovak Collection of Microorganisms, Brno, Czechoslovakia, as CCM 4109 and in the culture collection of the Laboratorium voor Microbiologie, Ghent, Belgium, as LMG 13028. The characteristics of the type strain conform to the description given above.

Six additional strains of Flavobacterium scophthalmum, MM1A (isolated from the gills of diseased turbot), MM1B (isolated from diseased turbot), M1D (isolated from diseased turbot), MM2B (isolated from seawater), MM2C (isolated from seawater), and MM4 (isolated from the gills of diseased turbot), have been deposited in the culture collection of the Laboratorium voor Microbiologie, Ghent, Belgium, as LMG 
TABLE 5. Differentiating characteristics of Flavobacterium scophthalmum and other taxa on the same rRNA homology branch in rRNA superfamily $\mathrm{V}$

\begin{tabular}{|c|c|c|c|c|c|c|c|}
\hline Taxon & $\begin{array}{l}\text { Acid } \\
\text { produced } \\
\text { from } \\
\text { glucose }\end{array}$ & $\begin{array}{c}\text { Growth at } 36^{\circ} \mathrm{C} \\
\text { on agar }\end{array}$ & $\begin{array}{c}\text { Growth on } \\
\text { MacConkey agar }\end{array}$ & $\begin{array}{l}\text { Nitrate } \\
\text { reduction }\end{array}$ & $\begin{array}{c}\text { Phenylalanine } \\
\text { deaminase }\end{array}$ & $\begin{array}{c}\text { Urea } \\
\text { degradation }\end{array}$ & $\begin{array}{c}\text { Indole } \\
\text { production }\end{array}$ \\
\hline Flavobacterium scophthalmum & $-a$ & - & - & - & + & + & - \\
\hline Flavobacterium balustinum & + & - & + & + & - & - & + \\
\hline Flavobacterium gleum & + & + & + & $\mathrm{v}$ & - & $\mathrm{v}$ & + \\
\hline Flavobacterium indologenes & + & + & $\mathbf{v}$ & $\mathrm{V}$ & - & - & + \\
\hline Flavobacterium indoltheticum & + & + & + & - & ND & - & + \\
\hline
\end{tabular}

${ }^{a}+$, positive; -, negative; v, variable; ND, not determined. Data are from references 12,13 , and 30 and this study.

13029, LMG 13030, LMG 13031, LMG 13032, LMG 13033, and LMG 13034, respectively.

Differential characteristics for Flavobacterium scophthalmum and allied bacteria are shown in Tables 1 and 5 .

\section{ACKNOWLEDGMENTS}

Richard Tytgat determined the G+C contents of the DNAs. James Buchanan provided assistance with transmission electron microscopy and photography. J.F.B. thanks K. Kersters for hospitality in the Laboratorium voor Microbiologie, Universiteit Gent, Ghent, Belgium.

M.M. gratefully acknowledges funding from the Saudi Arabian government. Part of this research was performed within the framework of CEC contract BIOT-CT91-0294.

\section{REFERENCES}

1. Aiba, H., S. Adhya, and B. de Crombrugghe. 1981. Evidence for two functional gal promoters in intact Escherichia coli cells. J. Biol. Chem. 256:11905-11910.

2. Anacker, R. L., and E. J. Ordal. 1955. Study of bacteriophage infecting the myxobacterium Chondrococcus columnaris. J. Bacteriol. 70:738-741.

3. Austin, B., and D. A. Austin. 1993. Bacterial fish pathogens: disease in farmed and wild fish, 2nd ed. Simon \& Schuster, Chichester, England.

3a.Bernardet, J. F. Unpublished data.

4. Bernardet, J. F., and P. A. D. Grimont. 1989. Deoxyribonucleic acid relatedness and phenotypic characterization of Flexibacter columnaris sp. nov., nom. rev., Flexibacter psychrophilus sp. nov., nom. rev., and Flexibacter maritimus Wakabayashi, Hikida, and Masumura 1986. Int. J. Syst. Bacteriol. 39:346-354

4a.Bernardet, J. F., and P. Segers. Unpublished data.

5. Brenner, D. J., A. C. McWhorter, J. K. Leete Knutson, and A. G. Steigerwalt. 1982. Escherichia vulneris: a new species of Enterobacteriaceae associated with human wounds. J. Clin. Microbiol. 15: 1133-1140.

6. Christensen, P. J. 1977. Synonymy of Flavobacterium pectinovorum Dorey with Cytophaga johnsonae Stanier. Int. J. Syst. Bacteriol. 27:122-132.

7. Cowan, S. T. 1974. Cowan \& Steel's manual for the identification of medical bacteria, 2nd ed. Cambridge University Press, Cambridge.

8. De Ley, J. 1970. Reexamination of the association between melting point, buoyant density, and chemical base composition of deoxyribonucleic acid. J. Bacteriol. 101:738-754.

9. De Ley, J., H. Cattoir, and A. Reynaerts. 1970. The quantitative measurement of DNA hybridization from renaturation rates. Eur. J. Biochem. 12:133-142

10. De Ley, J., and J. De Smedt. 1975. Improvements on the membrane filter method for DNA:rRNA hybridization. Antonie van Leeuwenhoek J. Microbiol. Serol. 41:287-307.

11. Gerhardt, P., R. G. E. Murray, R. N. Costilow, E. W. Nester, W. A. Wood, N. R. Krieg, and G. B. Phillips (ed.). 1981. Manual of methods for general bacteriology. American Society for Microbiology, Washington, D.C.
12. Holmes, B., R. J. Owen, and T. A. McMeekin. 1984. Genus Flavobacterium Harrison, Breed, Hammer and Huntoon 1923, $97^{\mathrm{AL}}$, p. 353-361. In N. R. Krieg and J. G. Holt (ed.), Bergey's manual of systematic bacteriology, vol. 1. Williams and Wilkins, Baltimore.

13. Holmes, B., R. J. Owen, A. G. Steigerwalt, and D. J. Brenner. 1984. Flavobacterium gleum, a new species found in human clinical specimens. Int. J. Syst. Bacteriol. 34:21-25.

14. Lewin, R. A., and D. M. Lounsbery. 1969. Isolation, cultivation, and characterization of flexibacteria. J. Gen. Microbiol. 58:154170.

15. Liston, J., W. Weibe, and R. R. Colwell. 1963. Quantitative approach to the study of bacterial species. J. Bacteriol. 85:10611070.

16. Marmur, J., and P. Doty. 1962. Determination of the base composition of deoxyribonucleic acid from its thermal denaturation temperature. J. Mol. Biol. 5:109-118.

17. Millonig, G. 1961. A modified procedure for lead staining of thin sections. J. Biophys. Biochem. Cytol. 11:736.

18. Mudarris, M., and B. Austin. 1988. Quantitative and qualitative studies of the bacterial microflora of turbot, Scophthalmus maximus L., gills. J. Fish Biol. 32:223-229.

19. Mudarris, M., and B. Austin. 1989. Systemic disease in turbot, Scophthalmus maximus L., caused by a previously unrecognised Cytophaga-like bacterium. Dis. Aquat. Org. 6:161-166.

20. Popoff, M. Y., C. Coynault, M. Kiredjian, and M. Lemelin. 1981. Polynucleotide sequence relatedness among motile Aeromonas species. Curr. Microbiol. 5:109-114.

21. Reichenbach, H., and M. Dworkin. 1981. The order Cytophagales (with addenda on the genera Herpetosiphon, Saprospira and Flexithrix), p. 356-379. In M. P. Starr, H. Stolp, H. G. Trüper, A. Balows, and H. G. Schlegel (ed.), The prokaryotes. A handbook on habitats, isolation and identification of bacteria, vol. 1. Springer-Verlag, Berlin.

22. Reynolds, E. S. 1963. The use of lead citrate at high $\mathrm{pH}$ as an electron-opaque stain in electron microscopy. J. Cell Biol. 17:208221.

23. Segers, P., W. Mannheim, M. Vancanneyt, K. de Brandt, K.-H. Hinz, K. Kersters, and P. Vandamme. Description of Riemerella anatipestifer gen. nov., comb. nov., the causative agent of Septicaemia Anserum Exsudativa, and its phylogenetic affiliation within the Flavobacterium-Cytophaga rRNA homology group. Int. J. Syst. Bacteriol., in press.

24. Skerman, V. B. D., V. McGowan, and P. H. A. Sneath (ed.). 1980. Approved lists of bacterial names. Int. J. Syst. Bacteriol. 30:225420.

25. Skerratt, J. H., P. D. Nichols, C. A. Mancuso, S. R. James, S. J. Dobson, T. A. McMeekin, and H. Burton. 1991. The phospho-lipid ester-linked fatty acid composition of members of the family Halomonadaceae and genus Flavobacterium. A chemotaxonomic study. Syst. Appl. Microbiol. 14:8-13.

26. Vandamme, P., P. Segers, M. Vancanneyt, K. Van Hove, R. Mutters, J. Hommez, F. Dewhirst, B. Paster, K. Kersters, E. Falsen, L. Devrieze, K.-H. Hinz, and W. Mannheim. 1994. Ornithobacterium rhinotracheale gen. nov., sp. nov., isolated from the 
avian respiratory tract. Int. J. Syst. Bacteriol. 44:24-37.

27. van der Meulen, H. J., W. Harder, and H. Veldkamp. 1974. Isolation and characterization of Cytophaga flevensis sp. nov., a new agarolytic flexibacterium. Antonie van Leeuwenhoek J. Microbiol. Serol. 40:329-346.

28. Vauterin, L., P. Yang, B. Hoste, M. Vancanneyt, E. L. Civerolo, J. Swings, and K. Kersters. 1991. Differentiation of Xanthomonas campestris pv. citri strains by sodium dodecyl sulfate-polyacrylamide gel electrophoresis of proteins, fatty acid analysis, and
DNA-DNA hybridization. Int. J. Syst. Bacteriol. 41:535-542.

29. Watson, M. L. 1958. Staining of tissue sections for electron microscopy with heavy metals. J. Biophys. Biochem. Cytol. 4:475. 30. Yabuuchi, E., T. Kaneko, I. Yano, C. W. Moss, and N. Miyoshi. 1983. Sphingobacterium gen. nov., Sphingobacterium spiritivorum comb. nov., Sphingobacterium multivorum comb. nov., Sphingobacterium mizutae sp. nov., and Flavobacterium indologenes sp. nov.: glucose-nonfermenting gram-negative rods in CDC groups IIK-2 and IIb. Int. J. Syst. Bacteriol. 33:580-598. 